\title{
Pendampingan Belajar Matematika Bagi Anak Berkebutuhan Khusus di SLB Bhakti Luhur Kota Madiun
}

\author{
Gregoria Ariyanti ${ }^{1}$, Ana Easti Rahayu Maya Sari ${ }^{2}$, David Ary Wicaksono ${ }^{3}$ \\ 1,2Universitas Katolik Widya Mandala Surabaya/Prodi Pendidikan Matematika \\ e-mail: 1ariyantigregoria@gmail.com,2anaeasti42@gmail.com \\ 3Universitas Katolik Widya Mandala Surabaya/Prodi Psikologi \\ e-mail: wicak_sono11@yahoo.com
}

\begin{abstract}
Abstrak
Pendidikan menjadi hak semua anak-anak Indonesia, termasuk juga anak berkebutuhan khusus (ABK). ABK memerlukan perlakuan khusus, demikian juga dalam pembelajaran. Perhatian yang diberikan kepada seluruh anak Indonesia sudah menjangkau semua kalangan demikian juga perhatian bagi anak berkebutuhan khusus. Hal itu tampak dengan adanya kurikulum dan sekolah yang mengkhususkan bagi anak-anak tersebut, demikian juga adanya pelajaran matematika sederhana. Tujuan kegiatan yang dilakukan ini yaitu memberikan pendampingan pemahaman konsep Matematika khususnya konsep Bilangan. Metode kegiatan pengabdian yang dilakukan berupa pendampingan dan perhatian bagi anak berkebutuhan khusus di SDLB Bhakti Luhur Kota Madiun. Hasil kegiatan pengabdian ini adalah meningkatnya kemampuan pemahaman konsep Matematika yaitu Bilangan bagi ABK.
\end{abstract}

Kata Kunci: anak berkebutuhan khusus, matematika, pendampingan belajar

\begin{abstract}
Education is the right of all Indonesian children, including children with special needs (ABK). Children with special needs require special treatment, as well as in learning. The attention given to all Indonesian children has reached all circles as well as attention to children with special needs. This can be seen by the existence of curricula and schools that specialize in these children, as well as the existence of simple mathematics lessons. The purpose of this activity is to assist in understanding the concept of mathematics, especially the concept of numbers. The method of service activities carried out is in the form of assistance and attention to children with special needs at SDLB Bhakti Luhur Madiun City. The result of this service activity is an increase in the ability to understand Mathematical concepts, namely Numbers for ABK.
\end{abstract}

Keywords: children with special needs, mathematics, learning assistance

\section{Pendahuluan}

Pertumbuhan dan perkembangan anak sangat dipengaruhi faktor internal (diri anak) dan faktor eksternal (luar diri anak). Anak memiliki tahap perkembangan diri yang berbeda. Terdapat juga kelompok anak yang memiliki keterbatasan baik fisik maupun psikis. Anak yang demikian dikatakan Anak Berkebutuhan Khusus (ABK) (UndangUndang Republik Indonesia Nomor 8 Tahun 2016 tentang Penyandang Disabilitas, 2016). 
ABK memiliki keadaan berupa penyimpangan dari anak pada umumnya yaitu dalam keadaan kurang atau melebihi anak pada umumnya (Desiningrum, 2016). Penyimpangan yang mereka miliki, membuat anak mengalami kendala untuk berkegiatan. Hal yang sama juga dikemukakan Directgov (Thompson, 2012), istilah anak berkebutuhan khusus mengacu pada kondisi anak yang memiliki kesulitan atau ketidakmampuan belajar yang mengakibatkan anak kesulitan belajar dibandingkan kebanyakan anak seusianya. Dengan adanya penyimpangan yang menghambat kegiatan dan perkembangan anak, maka anak demikian membutuhkan pelayanan khusus, sehingga Pemerintah memberikan perhatian berupa adanya sekolah inklusi (Cahyaningrum, 2012; Triyanto \& Permatasari, 2016).

Anak Berkebutuhan Khusus memiliki banyak kategori. Menurut Hallahan (Hallahan, D.P., Kauffman, J. M., \& Pullen, 2015), terdapat istilah disabilitas dan inabilitas. Lanjutnya, semua disabilitas merupakan inabilitas (ketidakmampuan) melakukan sesuatu, tetapi tidak semua inabilitas tersebut merupakan disabilitas. Perlu dipahami bahwa pertumbuhan dan perkembangan anak juga berdasarkan tahapan atau umur anak tersebut. Misalnya, anak usia 6 bulan masih dalam batas kewajaran tahap perkembangan jika tidak dapat berjalan atau bicara, dan hal ini bukan disabilitas melainkan inabilitas (ketidakmampuan).

Anak berkebutuhan khusus (ABK) adalah anak dengan karakteristik khusus yang biasanya berbeda dari anak pada umumnya yang menunjukkan kekurangan atau kelebihan dari segi mental, emosional, atau fisik. Kelompok anak dengan kekhususan ini memiliki hambatan belajar dan perkembangan (Geniofam, 2010). Oleh karena itu, anak demikian membutuhkan dampingan pendidikan yang disesuaikan hambatan belajar dan perkembangan yang dialami anak dengan jenis keterbatasan yang dimiliki (Aziz, A. N., Sugiman, \& Prabowo, 2015; Riadin, A., Misyanto, \& Usop, 2017; Thompson, 2012). Menurut Widinarsih (Widinarsih, 2019), istilah kekhususan yang dimiliki anak demikian, sering dikenal dengan istilah tuna atau cacat, memiliki beberapa jenis yaitu: tuna netra, tuna rungu, tuna grahita, tuna daksa, tuna laras, dan tuna wicara.

Matematika yang merupakan mata pelajaran wajib di sekolah umum, juga diberikan di beberapa sekolah inklusi. Untuk kondisi anak dengan kebutuhan khusus, tentunya juga mengalami kesulitan karena ketidakmampuan mereka. Ada beberapa istilah untuk mendefinisikan anak dengan ketidakmampuan dalam matematika, diantaranya Dyscalculia learning. Menurut Subini (Subini, 2011) dyscalculia learning adalah kesulitan menggunakan bahasa simbolik untuk berpikir, mencatat dan mengkomunikasikan pikiran yang berhubungan dengan angka atau besaran. Dyscalculia learning merupakan kendala bagi perkembangan kemampuan aritmatika atau kemampuan matematika, yang tentunya mempengaruhi prestasi akademik atau mempengaruhi kehidupan sehari-hari anak.

Untuk kondisi anak yang didampingi dalam kegiatan pengabdian ini, memiliki jenis kecacatan diantaranya tuna grahita sedang, ganda, dan nakal. Sebelum melakukan kegiatan pendampingan, tim pelaksana mengadakan observasi ke sekolah dan 
wawancara dengan guru kelas. Observasi dilakukan untuk mendapatkan informasi kondisi sekolah dan jenis kecacatan yang dimiliki anak. Berdasarkan hasil wawancara guru dan pendamping anak berkebutuhan khusus di SLB Bhakti Luhur Madiun Jl. A. Yani No. 17, Pangonganan, Madiun, Kota Madiun, Jawa Timur 63121, diperoleh data bahwa siswa merasa sulit untuk memahami dan menyelesaikan soal Matematika, salah satunya konsep Bilangan (berhitung). Selain itu, anak berkebutuhan khusus di SLB Bhakti Luhur sebagian besar masih terlalu bergantung kepada guru atau pendamping khususnya untuk hal-hal sederhana. Kegiatan pendampingan yang dilakukan ini merupakan kegiatan pengabdian masyarakat. Masyarakat yang dimaksud di sini adalah kelompok orang yang mempelajari Matematika, yaitu siswa Sekolah Luar Biasa (SLB). Kelompok siswa SLB merupakan salah satu kelompok masyarakat yang tidak produktif secara ekonomi.

Pada umumnya, seorang siswa dianggap berhasil jika memiliki kemampuan pemahaman materi khususnya di sekolah. Kemampuan pemahaman merupakan hasil yang dicapai subyek belajar setelah mengikuti proses pembelajaran. Hal ini juga berlaku bagi anak berkebutuhan khusus yang telah melalui pendampingan khusus. Dengan pendampingan ini, diharapkan agar siswa mempunyai kemampuan memahami konsep matematika, dalam hal ini adalah anak berkebutuhan khusus. Dengan adanya peningkatan kemampuan Matematika dimungkinkan dapat meningkatkan kepercayaan diri anak berkebutuhan khusus.

\section{Metode}

Pendampingan anak berkebutuhan khusus yang diadakan di SDLB Bhakti Luhur di Kecamatan Manguharjo Kota Madiun diikuti oleh 7 anak dengan jenis kecacatan yaitu tuna grahita sedang, ganda, dan nakal. Sehubungan dengan pendampingan yang diadakan di masa pandemi COVID-19, maka jumlah anak yang didampingi dibatasi dan waktu kegiatan juga dibatasi. Pendampingan dilakukan dengan tetap memperhatikan protokol kesehatan, yaitu mengecek suhu tubuh, mencuci tangan, menggunakan masker, anak-anak menggunakan face shield, dan menjaga jarak antar anak dan pendamping.

Kegiatan pengabdian diawali dengan mengidentifikasi bentuk pendampingan Matematika, yaitu konsep Bilangan. Selanjutnya diskusi pelaksana dalam teknik pelaksanaan pendampingan dan waktu pelaksanaan, pengadaan alat peraga dalam pemahaman konsep Matematika sederhana, dan pelaksanaan pendampingan anak. Pelaksanaan kegiatan berjalan dengan menggunakan strategi pendampingan serta pendekatan anak berkebutuhan khusus sehingga dapat melakukan aktivitas belajar dan memiliki kepercayaan diri yang tinggi. Kegiatan pendampingan yang dilaksanakan berbentuk pendampingan dan pendekatan secara personal bagi anak berkebutuhan khusus dalam penguasaan konsep Matematika sederhana yaitu Bilangan. Indikator keberhasilan kegiatan peningkatan pemahaman konsep Matematika bagi anak berkebutuhan khusus diberikan dalam Tabel 1. 
Tabel 1. Indikator Capaian

\begin{tabular}{|l|l|}
\hline \multicolumn{1}{|c|}{ Jenis Luaran } & \multicolumn{1}{c|}{ Indikator Capaian } \\
\hline $\begin{array}{l}\text { Peningkatan penguasaan konsep } \\
\text { Matematika sederhana bagi anak } \\
\text { berkebutuhan khusus }\end{array}$ & $\begin{array}{l}\text { Pengetahuan dan ketrampilan anak meningkat dalam } \\
\text { memahami Matematika khususnya Bilangan dan } \\
\text { berhitung (dalam angka presentase) }\end{array}$ \\
\hline
\end{tabular}

\section{Hasil dan Pembahasan}

Pendampingan belajar Matematika bagi anak berkebutuhan khusus dilakukan selama 6 pertemuan dan setiap pertemuan berlangsung 1 sampai 2 jam. Interval waktu pendampingan belajar Matematika dibuat tidak terlalu lama karena anak berkebutuhan khusus cenderung merasa jenuh. Untuk mengatasi kejenuhan tersebut, setelah mereka didampingi dalam belajar, anak berkebutuhan khusus diberi variasi kegiatan seperti mewarnai, menggambar, dan menulis. Sebanyak 7 anak berkebutuhan khusus yang terlibat dalam pendampingan belajar Matematika dengan jenis kecacatan yang berbeda. Sehingga anak tersebut didampingi oleh satu pendamping dari dosen atau mahasiswa. Pendampingan pada hari pertama diawali dengan tes Matematika untuk mengukur kemampuan awal anak terhadap Matematika. Pada Gambar 2 tampak anak berkebutuhan khusus sedang mengerjakan soal Matematika dan didampingi pendamping.
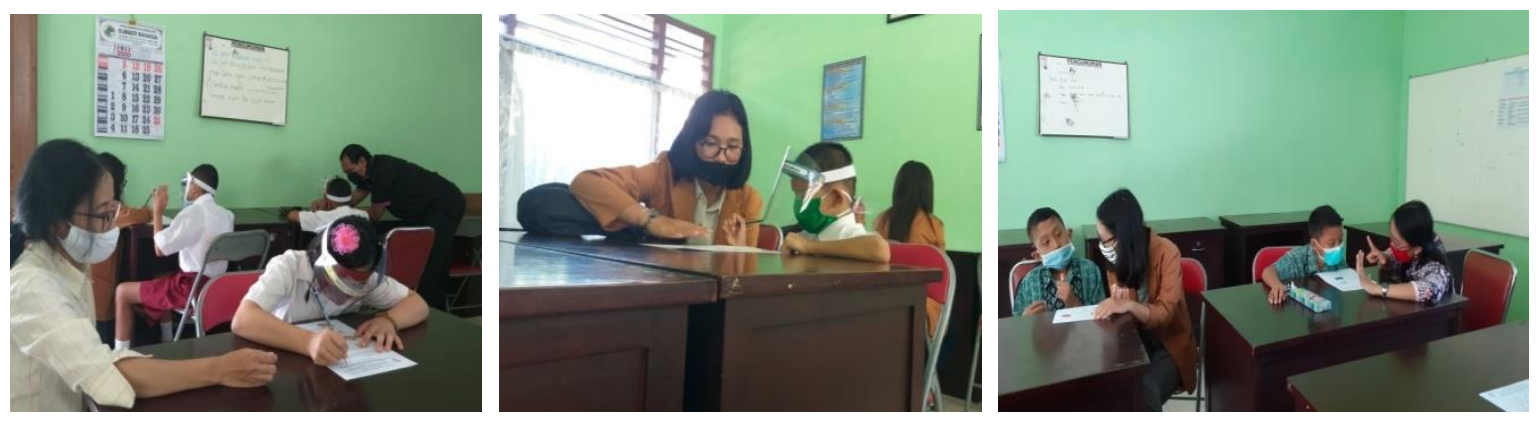

Gambar 2. Dosen dan Mahasiswa mendampingi siswa

Anak berkebutuhan khusus memberikan respon positif terhadap pendampingan yang dilakukan tim pelaksana. Hal tersebut tampak dari reaksi anak yang akan didampingi merasa gembira dan selalu siap hadir di ruangan sebelum jam pendampingan dimulai, serta anak-anak bisa bercanda dengan gembira dengan mahasiswa yang mendampingi mereka.

Setelah pelaksanaan pendampingan belajar Matematika bagi anak berkebutuhan khusus, pada pertemuan terakhir dilaksanakan postes kemampuan belajar Matematika. Nilai postes digunakan untuk mengetahui peningkatan penguasaan konsep matematika. Soal postes yang diberikan menyesuaikan dengan kemampuan anak berkebutuhan khusus. Rata-rata hasil pretes yaitu 37,14 dan rata-rata hasil postes 
49,29. Sehingga hasil postes mengalami peningkatan. Jika dilihat dari rata-rata tersebut, kemampuan penguasaan konsep Matematika mengalami kenaikan sebesar $32,71 \%$. Pada Tabel 3 berikut diberikan data nilai pretes dan postes anak berkebutuhan khusus yang didampingi.

Tabel 3. Data nilai Matematika sebelum dan sesudah pendampingan

\begin{tabular}{|c|l|c|c|c|c|}
\hline No. & Siswa & Kelas & Jenis Kecacatan & Nilai Pretes & Nilai Postes \\
\hline 1. & Siswa 1 & I & Tuna grahita sedang & 10 & 15 \\
\hline 2. & Siswa 2 & II & Nakal & 50 & 70 \\
\hline 3. & Siswa 3 & II & Nakal & 45 & 60 \\
\hline 4. & Siswa 4 & II & Nakal & 65 & 75 \\
\hline 5. & Siswa 5 & IV & Nakal & 45 & 60 \\
\hline 6. & Siswa 6 & V & Ganda & 30 & 45 \\
\hline 7. & Siswa 7 & VI & Tuna grahita sedang & 15 & 20 \\
\hline \multicolumn{7}{|c|}{ Rata-rata Kenaikan } & 37,14 & 49,29 \\
\hline \multicolumn{7}{|c|}{$32,71 \%$} \\
\hline
\end{tabular}

\section{Simpulan dan Rekomendasi}

Pendampingan sebaiknya diberikan secara rutin supaya anak memiliki kemampuan pengetahuan Matematika. Berdasarkan pengamatan tim pelaksana, siswa bersemangat dalam mengikuti setiap pendampingan. Respon dari guru pendamping juga sangat baik, terutama dalam mendukung pelaksanaan, memberikan motivasi, menyediakan tempat yang bisa digunakan untuk bimbingan, dan mengikuti kegiatan pendampingan. Secara keseluruhan, tidak ada kendala besar untuk semua kegiatan tersebut. Kendala sekunder yang dihadapi selama kegiatan adalah jumlah mahasiswa yang berkunjung tidak lengkap.Untuk dapat meningkatkan pemahaman konsep matematika bagi anak berkebutuhan khusus, masih diperlukan ketekunan dan keuletan para guru untuk mendampingi. Kegiatan ini berjalan dengan baik tampak dari adanya peningkatan nilai pretes dan postes kemampuan matematika anak berkebutuhan khusus.

\section{Penghargaan}

Ucapan terima kasih Penulis sampaikan kepada Kementerian Riset dan Teknologi (Kemenristek/BRIN) atas Hibah Pengabdian Kepada Masyarakat Stimulus (PKMS) 2020. Penulis juga menyampaikan terima kasih kepada Kepala Sekolah SDLB Bhakti Luhur Kota Madiun dan guru yang terlibat dalam kegiatan pendampingan belajar Matematika bagi anak berkebutuhan khusus.

\section{Daftar Pustaka}

Undang-Undang Republik Indonesia Nomor 8 Tahun 2016 tentang Penyandang Disabilitas, (2016).

Aziz, A. N., Sugiman, \& Prabowo, A. (2015). Analisis Proses Pembelajaran Matematika pada Anak Berkebutuhan Khusus (ABK) Slow Learner di Kelas Inklusi SMP 
Negeri 7 Salatiga. Kreano: Jurnal Matematika Kreatif-Inovatif, 6(2), 111-120.

Cahyaningrum, R. K. (2012). Tinjauan Psikologis Kesiapan Guru dalam Menangani Peserta Didik Berkebutuhan Khusus pada Program Inklusi (Studi Deskriptif di SD dan SMP Sekolah Alam Ar-Ridho). Educational Psychology Journal (EPJ), 1(1).

Desiningrum, D. R. (2016). Psikologi Anak Berkebutuhan Khusus. Psikosain.

Geniofam. (2010). Mengasuh dan Mensukseskan Anak Berkebutuhan Khusus. Gara Ilmu.

Hallahan, D.P., Kauffman, J. M., \& Pullen, P. C. (2015). Exceptional Learners (13th ed). Pearson Education, Inc.

Riadin, A., Misyanto, \& Usop, D. S. (2017). Karakteristik Anak Berkebutuhan Khusus di Sekolah Dasar Negeri (Inklusi) di Kota Palangka Raya. Anterior Jurnal, 17(1), 22-27.

Subini, N. (2011). Mengatasi Kesulitan Belajar Pada Anak. JAVANICA.

Thompson, J. (2012). Memahami Anak Berkebutuhan Khusus. Erlangga.

Triyanto \& Permatasari, D. R. (2016). Pemenuhan Hak Anak Berkebutuhan Khusus di Sekolah Inklusi. Jurnal UM, 25(2), 1760186.

Widinarsih, D. (2019). Penyandang Disabilitas di Indonesia: Perkembangan Istilah dan Definisi. Jurnal Ilmu Kesejahteraan Sosial, 20(2), 127-142. 